\title{
VALIDITAS DAN RELIABILITAS WARWICK-EDINBURG MENTAL WELL BEING SCALE
}

\author{
Hartanto* \\ hartantopaud@unwidha.ac.id
}

\begin{abstract}
Abstrak
Penelitian ini melakukan uji validasi dan uji reliabilitas mengenai konsep kesejahteraan mental melalui skala well being Warwick-Edinburg. Kesejahteraan mental atau akrab disebut sebagai mental well being adalah kondisi seorang individu yang merasakan kenyamanan dalam mind setnya mengenai kondisi mentalnya. Oleh karena itu, kondisi kesejahteraan mental sifatnya flutuatif dan relative. Meskipun demikian menurut pandangan peneliti, tetap ada kemungkinan konstruk mengenai kesejahteraan mental ini dialami dan dirasakan sama lintas budaya dan beberapa tidak. Metode penelitian ini menggunakan tehnik confirmatory factor analysis untuk melakukan penyelidikan mengenai konstruk laten dalam kesejahteraan mental dan uji reliabilitas menggunakan composite reliability dari Raykov. Subjek berkisar 200 orang dengan latar belakang pendidikan mahasiswa dan pelajar, yang berusia remaja.Piranti lunak yang digunakan adalah R version 3.2.1 (2014-10-31) -- "Pumkin Helmet" dan Lisrel 8.8.Hasil penelitian menjelaskan bahwa ada beberapa indikator kesejahteraan mental yang tidak memnuhi standart dan gugur. Model dalam menjelaskan antara matrix kovarian data dengan teori juga terbilang kurang fit. Meskipun demikian uji reliabilitas tercapai koefisien yang signifikan dan layak.
\end{abstract}

Keyword: kesejahteraan mental, validitas, reliabilitas

* Hartantoadalah Dosen Universitas Widya Dharma Klaten Jawa Tengah.

\section{PENDAHULUAN}

Kiranya, sangatlah tepat jika WHO menegaskan bahwa definisi sehat tidak hanya mencakup kondisi fisik semata dan absennya penyakit, namun juga kondisi mental dan spiritual (Mason \& Kearns, 2013), dengan kata lain konsep well being merupakan perjumpaan dari empat aspek utama: transendensi, psikologis, sosial dan subjektif well being (Zapalla, 2007; Angner, 2010). Dalam pandangan ilmu psikologi tradisional, keadaan sejahtera dan kondisi mental yang sehat berarti menggambarkan kondisi absennya stress, rasa bersalah dan bahkan depresi serta penguasaan diri terhadap symptom - symptom negative lainnya (Shanafelt, Novotny, Johnson, Zhao, Steensema, Lacy, Rubin, \& Sloan, 2005).Era psikologi positif menggeser paradigma tersebut dan melengkapi definisi well being sebagai titik keberfungsian secara optimal sisisisi dalam diri individu mencakup fisik, sosio-emotional, spiritual, 
kognitif, dan perilaku (Wajsblat, 2011). Konsep well being merupakan meta-konsep dengan banyak minikonsep didalamnya, secara global well being mencakup akan optimalisasi keberfungsian dalam berperilaku dan berpikir, kondisi kualitas hidup dan kondisi kesehatan fisik maupun mental (Bornstein, Davidson, Keyes, \& Moore, 2003; Humphreys, Goodman, \& Ogilvie, 2013; Tokuda, Doba, Butler, \& Paasche-Orlow, 2009). Oleh karena itu riset dan pengembangan pengukuran skala mengenai well being menjadi sangat luas dan beragam (Moore, Bates, BrierleyBowers, Taafe, \& Clymer, 2012).

Dalam cakupan lebih luas kaidah well being juga berkorelasi dengan faktor ekonomi, sospol, budaya (Rentfrow, Mellander, \& Florida, 2009; Jorgensen, Jamieson, \& Martin, 2010) dan juga kondisi penegakan HAM dalam suatu wilayah (Talbott, 2010). Memang sejauh ini budaya dengan dimensi individualistik selalu memberi pijakan bagi banyak teori dalam ilmu sosial untuk berkembang dan berkreasi, tak terkecuali ilmu psikologi.Namun, seperti yang diketahui bahwa selain dimensi budaya individualistik juga dikenal dimensi budaya kolektif dimana mensyaratkan karakter masyarakat yang menjunjung tinggi etika kebersamaan dalam setiap sendi kehidupannya (Shiraev, \& Levy, 2010).Dalam ilmu psikologi, permasalahan muncul ketika acuan dalam beberapa konsep/alat ukur meniti hanya pada satu generalisasi (nomotetik) (Proctor, \& Capaldi, 2006), yang tidak dipungkiri hal itu mengandung beberapa bias budaya, bahasa dan sistem kepercayaan (Jackson, 2006; Paddila \& Borsato, 2008), dan tidak terkecuali juga dalam pembakuan alat ukur tentang kesehatan dan kesejahteraan mental (Newbigging, Bola, \& Shah, 2008). Selain itu budaya dan bahasa juga berperan dalam mempengaruhi individu dalam menjawab dan memberikan respon terhadap pengukuran skala (Keith, 2011).

Pengembangan alat ukur terhadap kesejahteraan dan kesehatan mental WEMWBS (WarwickEdinburg Mental Well-Being Scale) saat ini mulai dilakukan dalam ranah lintas budaya (Tennant, Hiller, Fishwick, PlattJoseph, Weich, Parkinson, Secker, \& StewardBrown, 2007; Bartram, Yadegarfar, Sinclair, \& Baldwin, 2011). Mengingat skala WEMWBS muncul dan dikembangkan di budaya barat, maka akan sedikit banyak berbeda jika diaplikasikan di budaya timur (Taggart, Friede, Weich, Clarke, Johnson, \& Stewart-Brown, 2013). Hal tersebut yang juga akhirnya mendorong dilakukannya penelitian uji validitas dan reliabilitas skala WEMWBS dalam bahasa dan budaya Indonesia. Sejauh pengetahuan peneliti skala WEMWBS belum pernah dialih 
bahasakan kedalam bahasa

being.Pengembangan

dan

Indonesia, dan hal ini pula yang pengukuran skala WEMWBS mendorong peneliti untuk sekaligus melakukan uji validasi dan reliabilitas WEMWBS dalam bahasa Indonesia melalui pendekatan analisis faktor konfirmatori dan model persamaan struktural dari Raykov. Penelitian ini sekaligus bertujuan untuk memverifikasi informasi tentang faktor-faktor atau komponen-komponen penyusun skala WEMWBS dalam bahasa Indonesia melalui pendekatan analisis faktor konfirmatori dan persamaan model struktural.

Well being diartikan sebagai kondisi puncak manusia memperoleh keadaan baik dan sejahtera (Snyder \& Lopez, 2002), oleh Edward Deci dan Richard Ryan (teori determinasi diri), kondisi well being diartikan sebagai kebahagiaan maksimal dari rasa pencapaian individu. Hal ini berasal dari domain individu seseorang yang merupakan menifestasi dari rasa aktualisasi diri, dan motivasi internalnya (Ryan \& Deci, 2000;Ryan\& Huta, 2009).

Salah satu skala pengembangan dari afeksi well being adalah PANAS. Skala PANAS menjadi sangat popular karena bias sosial rendah, dan memiliki konsistensi reliabilitas yang tinggi dalam penelitian lintas budaya. Penggabungan dari sisi kognitif dan afeksi selanjutnya dirumuskan sebagai kondisi mental yang sejahtera atau mental well terbilang sangat baru dan belum banyak dilakukan pembakuan dalam penelitian lintas budaya.

Validitas sejatinya berafiliasi dengan ketepatan dan kesesuaian (Anastasi \& Urbina, 1997).Maksudnya adalah dalam suatu test yang diciptakan dengan tujuan untuk melakukan suatu pengukuran, maka konsep validitas adalah syarat mutlak yang harus dimiliki alat test tersebut (Ubina, 2004). Berangkat dari teori tersebut maka para ahlipun sepakat tentunya dari bermacam - macam disiplin ilmu - bahwa konsep validitas merupakan derajat sejauh mana suatutes dapat mengukur apa yang hendak diukurnya (Sawilowsky, 2007; Sireci, 2007), oleh karena itu studi validitas menjadi point yang sangat penting untuk selanjutnya menjaga kredibilitas ilmiah penilaian pendidikan dan psikologis (Sireci, 2007). Pendekatan dalam melakukan validitas konstruk dibagi 2 , yaitu : a) pendekatan multitrait-multimethod, b) analisis faktor eksploratori maupun konfirmatori.

Ide utama dalam konsep reliabilitas adalah pencapaian keajegan dalam setiap melakukan pengukuran. Reliabilitas disebut sebagai property dari skor (score properties), bukan sebagai property dari alat test itu sendiri (test properties), dimana skor yang 
didapat dari analisis suatu test dapat bervariasi antara satu dengan yang lain tergantung faktor - faktor yang mempengaruhinya (metode dan karakteristik subjek) (Feldt \& Brennan, 1989). Posisi reliabilitas sama pentingnya dengan validitas dalam tiap alat ukur. Suatu alat ukur yang reliable dapat mempertahankan konsistensi pengukurannya dalam suatu rentang waktu, dan juga antar penilai (rater) (Robert, 2006).

Analisis faktor berkaitan dengan validitas konstruk, dimana penggunaan tehnik analisis faktor dapat digunakan untuk melakukan uji validitas konstruk pada suatu alat ukur.Analisis faktor adalah sebuah prosedur dalam mengidentifikasi dan mengelompokkan item ataupun variabel dalam sebuah penelitian karena konstrak yang mirip.Kemiripan antar butir dinyatakan dengan tingginya korelasi antar aitem. Dalam analisis faktor, dikenal dua istilah konstrak yaitu konstrak empirik dan konstrak laten (McGrath, 2011). Walaupun sejatinya analisis faktor diperuntukkan terhadap analisis mengenai permodelan variabel laten (latent - variable model) (Gorard \& Taylor, 2004). Namun kedudukan analisis faktor menjadi sangat penting, ketika bisa digunakan untuk menguji validitas konstruk suatu alat test/skala, walaupun ada tehnik lain yang bisa digunakan, yaitu dengan multi trait - multi method matrix namun tehnik itu terlalu "mewah" dengan harus melakukan pembakuan pola matriks dan memenuhi syarat validitas diskriminan dan validitas konvergen, yang ternyata hanya sedikit peneliti dan ilmuwan yang pernah melakukan (Rao, \& Sinharay, 2007; Phye, Robinson, \& Levin, 2005). Teknisnya, sebelum melakukan CFA lebih dahulu memperhatikan mengenai asumsi dan syarat apa saja yang diperlukan, seperti misalnya konsep teoritik ketika akan melakukan CFA haruslah kuat dan fundamental, selain itu juga spesifikasi permodelan, jumlah sample, tehnik melakukan estimasi dan terakhir jenis parameter apa yang dipakai juga harus adekuat untuk menunjang hasil yang baik dan diterima (Thompson, 2004). Namun masalah muncul jika ternyata asumsi normalitas tidak terpenuhi, Menyikapi hal tersebut akhirnya Joreskog dan Sorbom (2004), dalam bukunya memberikan suatu tehnik alternative, yaitu dengan menambah jumlah matrix asymptotic covarian (asymptotic covariance matrix) kedalam metode yang pertama tadi, yaitu maximum likelihood.Transformasi itu menghasilkan estimasi yang tahan terhadap sebaran data tidak normal (robust maximum likelihood).

Selain itu langkah selanjutnya adalah menentukan jenis parameter. Hoper, Coughlan dan Mullen, (2008) membagi jenis parameter untuk menilai sebuah model cocok dan fit 
untuk dianalisis menjadi 3, yaitu parameter kecocokan absolute, parameter kecocokan inkremental, dan parameter kecocokan parsimoni. Parameter kecocokan absolute berguna untuk menentukan prediksi model keseluruhan terhadap kecocokan antara matrix korelasi dengan covarian. Parameter kecocokan absolute terdiri dari model Root Mean Square Error of Approximation (RMSEA), Chi Square $\left(\mathrm{x}^{2}\right)$, Goodness of Fit Statistic (GFI), Adjusted of Goodness of Fit Statistic (AGFI), Root Mean Square Residual (RMR) dan terakhir Standardised Root Mean Square Residual (SRMR). Selanjutnya parameter kecocokan inkremental berguna dalam membandingkan struktur model yang dirangkai dengan model dasar atau model standard (null model).Parameter kecocokan inkremental terdiri dari Normed - Fit Index (NFI) dan Comparative Fit Index (CFI).Parameter yang terakhir adalah parameter kecocokan parsimoni yang mengaitkan derajat kecocokan model dengan jumlah parameter yang diestimasi.Parameter ini terdiri dari Parsimony Goodness-of-Fit Index (PGFI) dan Parsimonious Normed Fit Index (PNFI). Begitu banyak estimasi yang harus dilakukan untuk mendapatkan hasil yang optimal, namun ada beberapa estimasi yang menurut para ahli, wajib dilaporkan dalam penelitian analisis faktor konfirmatori, yaitu ukuran kecocokan Chi - Square, degree of freedom, $p$ - value, RMSEA, CFI dan SRMR (Kline, 2011).

Model persamaan struktual (SEM), merupakan salah satu tehnik untuk melakukan analisa variable latent seperti halnya analisis faktor dan teori respon item. SEM merupakan tehnik analisis statistic yang mampu menganalisis secara serempak pola hubungan antara konstrak laten dan indikatornya, konstrak laten terhadap yang lain serta menghitung kesalahan pengukuran (measurement error). SEM adalah gabungan evolusi dari analisis persamaan regresi berganda (statistic/structural model) dan permodelan analisis faktor (psychometric

properties/measurement model) (Hair, Anderson, Thatam, \& Black. 1995).

Penelitian ini menggunakan pendekatan model persamaan structural dari Raykov untuk mengukur koefisien reliabilitas alat ukur Warwick - Edinburg Mental Well Being. Reliabilitas komposit Raykov merupakan jenis reliabilitas gabungan dari tiap - tiap variable laten/indikator, yang berawal dari perhitungan matematis dalam mencari koefisien dari reliabilitas yang tahan pelanggaran asumsi. Rumus matematik yang sering dipakai untuk menghitung reliabilitas komposit dengan structural model adalah sebagai berikut : 


$$
\rho_{c}=\frac{(\Sigma \lambda)^{2}}{\left[(\Sigma \lambda)^{2}+\Sigma(\Theta)\right]}
$$

$\rho=$ Reliabilitas komposit,

$\lambda=$ loading indikator, dan

$\Theta=$ error variance indikator

Pendekatan Raykov diambil karena perhitungan reliabilitas yang tahan akan pelanggaran asumsi. Biasanya analisis yang banyak dilakukan dalam penelitian untuk mencapai kelayakan koefisien reliabilitas adalah dengan melakukan analisis cronbach Alpa. Meskipun mencukupi untuk nilai praktis dan efisiensi, namun ternyata cronbach Alpa memiliki beberapa kelemahan. Apalagi ketika asumsi utama dalam penggunaan cronbach Alpa secara periodik dilanggar. Asumsi utama penggunaan cronbach Alpa adalah norma essentially tau equivalent dan error yang tidak berhubungan (uncorrelated error) dalam suatu administrasi alat test (Raykov, 1997a; Raykov, 2007; Socan, 2000; Sijtsma, 2009). Sejatinya cronbach alpha berdiri diatas asumsi bahwa proporsi setiap aitem (faktor loading) adalah parallel dan sejajar, dan error dari setiap aitem bersifat independent (uncorrelated) (Graham, 2006). Konsistensi koefisien cronbach alpa sangat bergantung pada asumsi dasar diatas, yang apabila dilanggar maka hasil reliabilitas yang dihasilkan akan bias/nilai dibatas estimasi terendah (lower-bound estimates). Subjek yang sama, waktu yang sama dan mengukur atribut yang sama, namun mempunyai dua item tes yang saling paralel satu sama lain akan menghasilkan nilai skor murni yang konstan, walaupun varian kesalahan belum tentu sama.

Selain itu asumsi yang kedua, pemakaian cronbach alpha menuntut tidak tercapainya kovalen error antar item, jika dilihat teknisnya, konsistensi internal cronbach alpha adalah konsistensi antar item dalam tes, dengan melihat korelasi antar item dengan item total. Jadi analisisnya menggunakan distribusi varians antar item tes bukan skor tes. Dalam analisis reliabilitas suatu alat test permasalahan muncul ketika, suatu alat tes diberikan secara satu kali administrasi, memiliki karakteristik item yang hampir sama (sehingga jawaban yang akan dipilih cenderung karena kesesuaian bahasa antar item), dan karakteristik individu yang merespon beberapa item secara normative dan selalu mengikuti jawaban dan logika dari item yang sebelumnya, maka koefisien cronbach alpa akan menjadi bias (karena error antar item menjadi berkorelasi) dan otomatis hal itu yang nantinya akan menghasilkan error yang berkorelasi. Dalam ilmu psikologi dan bidang pengukuran akan selalu ada bermacam cara untuk menghasilkan error yang saling berkorelasi. Error berkorelasi dapat diantisipasi dengan melakukan analisis struktural antar variabel laten dan mempresisikan model estimasi (advanced step). 


\section{METODE PENELITIAN}

Subjek penelitian ini secara keseluruhan berjumlah sebanyak 200 orang. Hal itu termasuk adekuat, mengingat dalam SEM jumlah sampel yang tepat (appropriate) untuk dilaksanakannya analisis adalah dengan memenuhi formula 10 sampai 15 subjek sampel per variable indikator, jadi ketika jumlah variable indikator sebanyak 14, maka jumlah subjek sampel sebanyak 200 adalah memenuhi kriteria (Sacolo, Chung, Chu, Liao, Hua - Chen, Liang-Ou, I Chang, \& Chou, 2013).

Instrumen yang jelas dipakai dalam riset ini adalah skala Warwick

- Edinburg Mental Well Being dalam bahasa Indonesia yang dilakukan adaptasi dari skala Warwick Edinburg Mental Well Being versi bahasa Inggris yang dikembangkan oleh Warwick dan Edinburg. Skala tersebut dikembangkan untuk memenuhi kebutuhan akan instrument singkat yang mengukur komponen dari WEMWBS.

Instrumen WEMWBS ini berbentuk skala likert dengan lima alternatif jawaban yang menunjukkan tingkat kesesuaian subjek terhadap pernyataan. Berbeda dengan skala likert yang pada umumnya diisi dengan memberikan tanda centang (v) pada kolom jawaban, pada skala ini subjek diminta untuk memberikan angka didepan setiap pernyataan yang ada. Norma penilaian mengenai instrument WEMWBS bergerak dari sangat sesuai, sesuai, jarang, tidak sesuai dan sangat tidak sesuai.

Pengujian validitas konstruk yang akan dilakukan dalam penelitian ini menggunakan tehnik analisis faktor konfirmatori. Tehnik CFA peneliti menggunakan piranti lunak R, sedangkan pengujian reliabilitas data menggunakan piranti lunak LISREL 8.80 (Joreskog \& Sorbon, 2006).

\section{HASIL DAN PEMBAHASAN}

Uji prasyarat analisis dilakukan terlebih dahulu dengan menguji sebaran data untuk mencapai sebaran normal. Sebuah data dikatakan mempunyai sebaran yang normal apabila memiliki nilai $\mathrm{p}$ lebih dari 0.05 dari skewness dan kurtosis dalam uji normalitas multivariate (Viera, 2011).

\section{Analisis Model CFA}

Model yang akan diestimasi akan diuji melalui persamaan model structural dengan menggunakan piranti lunak R Core Team. Analisis data secara default menggunakan metode estimasi Maximum Likehood (ML). Parameter yang digunakan untuk menguji ketepatan model adalah Chi-square, derajat kebebasan, nilai $\mathrm{p}$ dan RMSE, CFI, SRMR serta GFI. Model secara keseluruhan analisis faktor konfirmatori dapat dilihat pada gambar dibawah ini : 


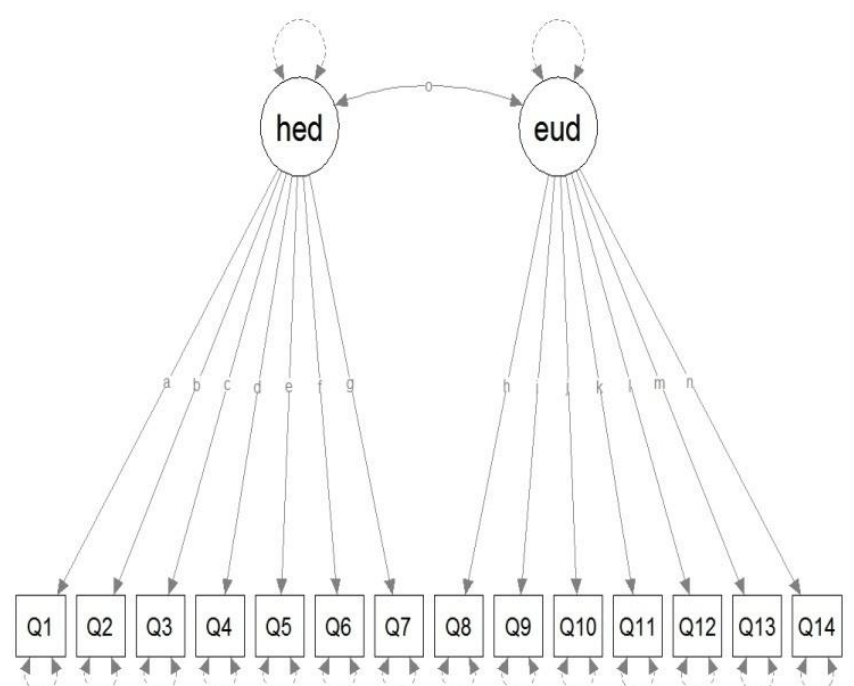

Gambar 1. Analisis Faktor Konfirmatori WEMWBS

$\mathrm{R}$ menggunakan packages untuk menjalankan fungsinya dalam menganalisa data. Packages didapat dari open-source pada ahli statistik. Pada dasarnya $\mathrm{R}$ berbasis command line interface, jadi untuk mengeluarkan image untuk menggambarkan model CFA agak susah, walapun dengan bantuan Analisis antara image yg muncul dan data tersaji secara terpisah, oleh karena itu peneliti sajikan mengenai notasi angka sebagaimana dibawah ini :

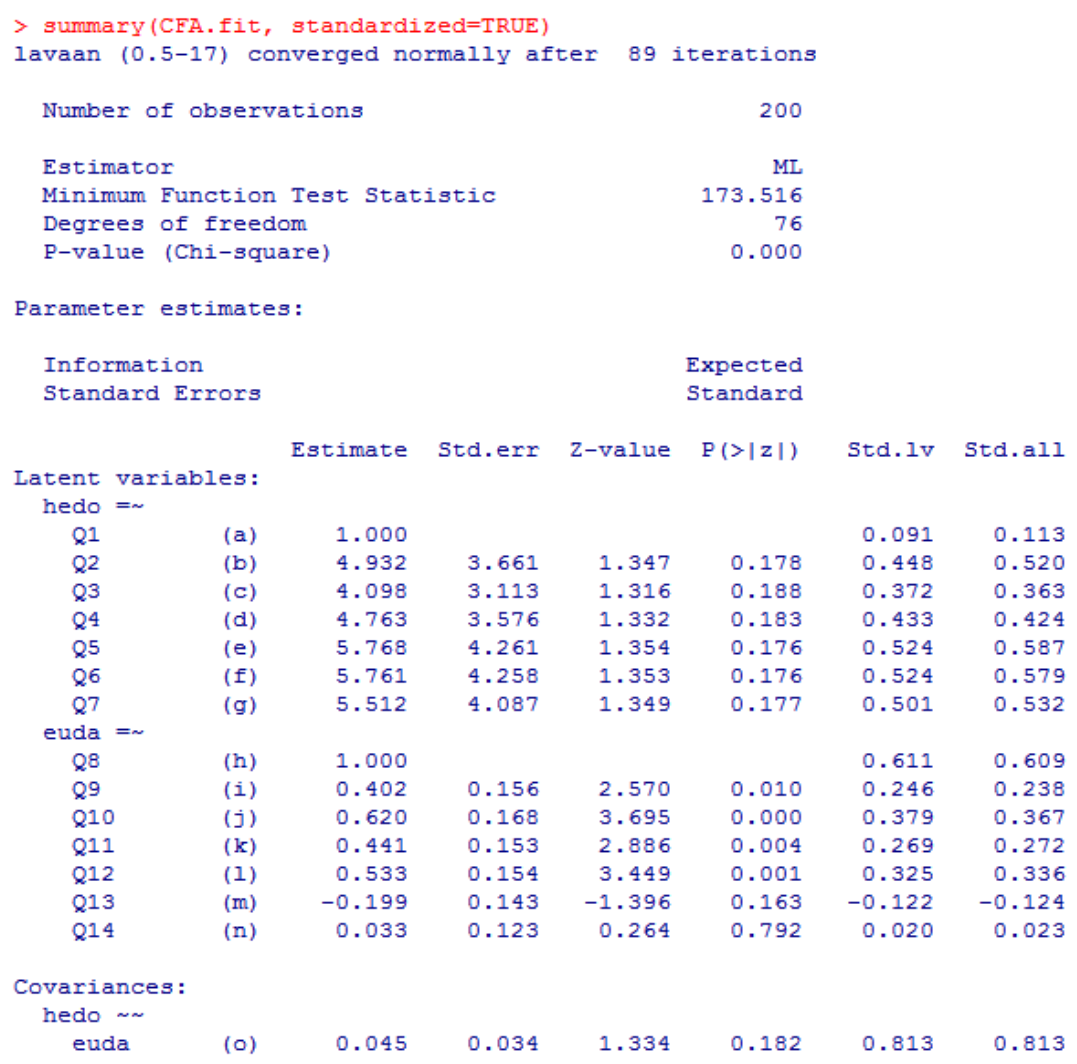


Dapat diketahui bahwa uji ketepatan model menghasilkan Chisquare $=173.51$, df $=76$, nilai $\mathrm{p}=$ 0.00, dan RMSEA $=0.080$. Chi$\operatorname{square}\left(\chi^{2}\right)$ berguna untuk menguji seberapa dekat kecocokan (closedfit) antara matrik kovarian model dengan matrik kovarian sample data. Nilai Chi-square ( $\left.\chi^{2}\right)$, derajat kebebasan (df) yang rendah, serta tingkat signifikansi yang besar atau sama dengan $0.05 \quad(p>0.05)$ menunjukan bahwa tidak ada perbedaan secara statistik antara matrik input yang diprediksi dengan matrik yangsebenarnya. Pada model di atas nilai Chi-square dan derajat kebebasan masih tergolong tinggi yakni $(\chi 2)$ sebesar 173.51 serta (df) sebesar 76, sehingga menghasilkan nilai $\mathrm{p}$ yang signifikan $(\mathrm{p}>0.05=$ 0.00). Hal tersebut menunjukkan bahwa terdapat ketidakcocokan antara model atau teori yang diuji dengan data matrix yang ada. However, ini tidak berarti model ini tidak berguna karena dari sini bisa dilihat mengenai kemungkinan jenis sample, besar kecilnya dan pelanggaran asumsi. Ini menarik karena hasil dari RMSEA (Root Mean Square Error of Approximation) yang merupakan uji ketepatan yang menjelaskan residual yang terdapat di dalam suatu model mencapai derajat yang good fit. Logikanya, nilai yang diharapkan dari RMSEA sangatlah kecil. Pada penelitian ini model yang dianalisis memiliki nilai RMSEA 0.080 yang menunjukkan bahwa terdapat kecocokan antara model atau teori yang diuji dengan data yang ada. Selain itu nilai CFI sebesar 0,77, SRMR sebesar 0,09, serta GFI sebesar 0,84 menunjukkan bahwa model yang diestimasi mendekati derajat fit model. Berdasarkan indeks ketepatan model yang secara keseluruhan tidak terpenuhi, maka dapat disimpulkan bahwa model yang disusun kurang sesuai dengan teori yang ada. Solusi yang bisa digunakan adalah menggunakan saran dari modificationIndexs, namun oleh Joreskog dan Sorbom, penggunaan modificationIndexs dianggap tehnik yang kurang diminati apabila teori dasar yang mendukungnya tidak ada. Selain itu modificationIndexs dalam $\mathrm{R}$, tidak memberikan syntax command line bagaimana tata cara melakukan modifikasi (Beaujean, 2014).

Tokoh seperti Kenny, Kashy, dan Bolger (1998) serta Harrington (2009) juga mengemukakan bahwa memodifikasi model dengan menghubungkan dan melepaskan kesalahan pengukuran sehingga tercapai 1 konstruk baru sebaiknya dihindari terutama apabila teori yang mendasarinya tidak kuat. Meskipun demikian terdapat 1 aitem (aitem 13) yang kesalahan pengukurannya saling berhubungan sehingga dicapai hasil yang negatif. Brown (2006), menjelaskan bahwa kesalahan pengukuran yang saling berhubungan antar aitem dapat disebabkan 
beberapa hal, yakni, aitem-aitem yang penyekorannya dibalik, aitemaitem yang hampir sama frase atau kalimatnya (sehingga subjek akan menjawab mengikuti alur logika item yang terdahulu), aitem-aitem yang mempunyai social desirability tinggi, dan aitem-aitem yang susah dimaknai.
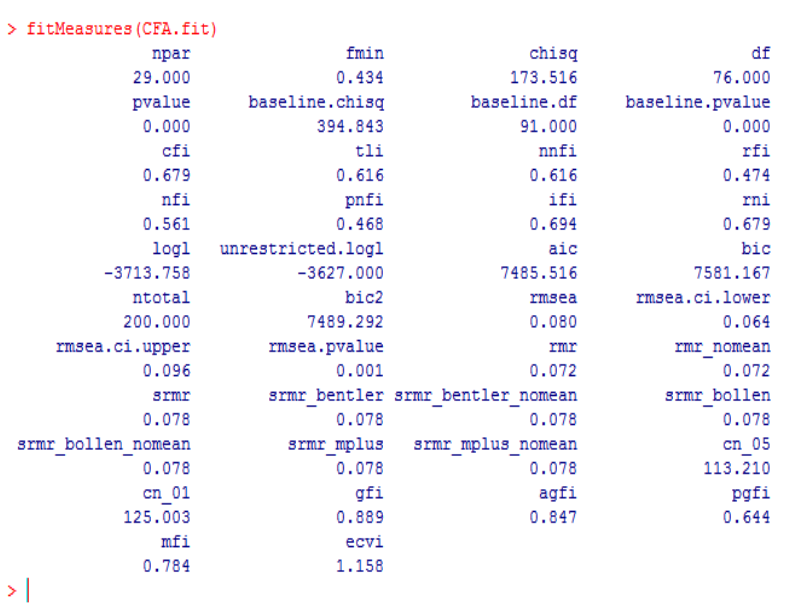

\begin{tabular}{|c|c|c|c|c|c|c|c|c|c|c|}
\hline \multicolumn{4}{|c|}{ lns op rhs label } & \multicolumn{6}{|c|}{ se } & std.nox \\
\hline & hedo $=\sim$ & Q1 & & a 1.000 & 0.000 & NA & $\mathrm{NA}$ & 0.091 & 0.113 & 0.113 \\
\hline & hedo $=\sim$ & $Q^{2}$ & & b $\quad 4.932$ & 3.661 & 1.347 & 0.178 & 0.448 & 0.520 & 0.520 \\
\hline & hedo $=\sim$ & $Q^{3}$ & & c 4.098 & 3.113 & 1.316 & 0.188 & 0.372 & 0.363 & 0.363 \\
\hline & hedo $=\sim$ & $Q^{4}$ & & d 4.763 & 3.576 & 1.332 & 0.183 & 0.433 & 0.424 & 0.424 \\
\hline & hedo $=\sim$ & 25 & & e 5.768 & 4.261 & 1.354 & 0.176 & 0.524 & 0.587 & 0.587 \\
\hline & hedo $=\sim$ & Q6 & & f 5.761 & 4.258 & 1.353 & 0.176 & 0.524 & 0.579 & 0.579 \\
\hline & hedo $=\sim$ & Q7 & & g 5.512 & 4.087 & 1.349 & 0.177 & 0.501 & 0.532 & 0.532 \\
\hline & euda $=\sim$ & $Q^{8}$ & & h 1.000 & 0.000 & NA & NA & 0.611 & 0.609 & 0.609 \\
\hline & euda $=\sim$ & $Q 9$ & & i $\quad 0.402$ & 0.156 & 2.570 & 0.010 & 0.246 & 0.238 & 0.238 \\
\hline 0 & euda $=\sim$ & Q10 & & j 0.620 & 0.168 & 3.695 & 0.000 & 0.379 & 0.367 & 0.367 \\
\hline & euda $=\sim$ & Q11 & & k $\quad 0.441$ & 0.153 & 2.886 & 0.004 & 0.269 & 0.272 & 0.272 \\
\hline & euda $=\sim$ & Q12 & & 10.533 & 0.154 & 3.449 & 0.001 & 0.325 & 0.336 & 0.336 \\
\hline 13 & euda $=\sim$ & Q13 & & m -0.199 & 0.143 & -1.396 & 0.163 & -0.122 & -0.124 & -0.124 \\
\hline 4 & euda $=\sim$ & Q14 & & n $\quad 0.033$ & 0.123 & 0.264 & 0.792 & 0.020 & 0.023 & 0.023 \\
\hline 15 & hedo $\sim$ & euda & & $\circ \quad 0.045$ & 0.034 & 1.334 & 0.182 & 0.813 & 0.813 & 0.813 \\
\hline 1 & Q1 & Q1 & & 0.637 & 0.064 & 9.952 & 0.000 & 0.637 & 0.987 & 0.987 \\
\hline 1 & Q2 & $Q^{2}$ & & 0.543 & 0.063 & 8.601 & 0.000 & 0.543 & 0.730 & 0.730 \\
\hline 18 & $Q^{3} \sim \sim$ & $Q^{3}$ & & 0.911 & 0.097 & 9.429 & 0.000 & 0.911 & 0.868 & 0.868 \\
\hline 19 & $Q^{4} \sim \sim$ & $Q^{4}$ & & 0.857 & 0.093 & 9.178 & 0.000 & 0.857 & 0.821 & 0.821 \\
\hline 20 & $Q 5 \sim \sim$ & Q5 & & 0.522 & 0.065 & 8.001 & 0.000 & 0.522 & 0.655 & 0.655 \\
\hline 21 & Q6 & $Q 6$ & & 0.545 & 0.067 & 8.089 & 0.000 & 0.545 & 0.665 & 0.665 \\
\hline 2 & Q7 & Q7 & & 0.636 & 0.075 & 8.507 & 0.000 & 0.636 & 0.717 & 0.717 \\
\hline 23 & $Q^{8} \sim$ & $Q^{8}$ & & 0.634 & 0.100 & 6.329 & 0.000 & 0.634 & 0.629 & 0.629 \\
\hline 24 & Q9 & Q9 & & 1.004 & 0.104 & 9.672 & 0.000 & 1.004 & 0.943 & 0.943 \\
\hline 25 & Q10 & Q10 & & 0.921 & 0.101 & 9.134 & 0.000 & 0.921 & 0.865 & 0.865 \\
\hline 26 & Q11 & Q11 & & 0.911 & 0.095 & 9.564 & 0.000 & 0.911 & 0.926 & 0.926 \\
\hline 27 & Q12 & Q12 & & 0.830 & 0.089 & 9.296 & 0.000 & 0.830 & 0.887 & 0.887 \\
\hline 28 & Q13 & Q13 & & 0.946 & 0.095 & 9.915 & 0.000 & 0.946 & 0.985 & 0.985 \\
\hline 29 & Q14 & Q14 & & 0.736 & 0.074 & 9.997 & 0.000 & 0.736 & 0.999 & 0.999 \\
\hline 30 & hedo & hedo & & 0.008 & 0.012 & 0.685 & 0.493 & 1.000 & 1.000 & 1.000 \\
\hline 31 & euda & euda & & 0.373 & 0.110 & 3.390 & 0.001 & 1.000 & 1.000 & 1.000 \\
\hline
\end{tabular}

Uji Reliabilitas Komposit

Berdasarkan nilai pada matrik lambda $X$ dan theta delta (karena tidak membutuhkan variable eksogen), maka perhitungan untuk reliabilitas komposit dilakukan sebagai berikut :

Reliable Composit

Standardized Solution

\section{LAMBDA-X}

hedo euda

Q1 $0.09 \quad--$

Q2

0.45

Q3

0.37

Q4

0.43

Q5 0.53

$\begin{array}{ccc}\text { Q6 } & 0.52 & -- \\ \text { Q7 } & 0.50 & -- \\ \text { Q8 } & - \text { - } & 0.61 \\ \text { Q9 } & - \text { - } & 0.25 \\ \text { Q10 } & -- & 0.38 \\ \text { Q11 } & -- & 0.27 \\ \text { Q12 } & -- & 0.33 \\ \text { Q13 } & -- & -0.12 \\ \text { Q14 } & -- & 0.02\end{array}$

PHI

$\begin{array}{lll} & \text { hedo } & \text { euda } \\ \text {------ } & ------ \\ \text { hedo } & 1.00 & \\ \text { euda } & 0.81 & 1.00\end{array}$


Reliable Composit

Completely Standardized Solution

LAMBDA-X

hedo euda

$\begin{array}{ccc} & ---- & ----- \\ \text { Q1 } & 0.11 & -- \\ \text { Q2 } & 0.52 & -- \\ \text { Q3 } & 0.36 & -- \\ \text { Q4 } & 0.42 & -- \\ \text { Q5 } & 0.59 & -- \\ \text { Q6 } & 0.58 & -- \\ \text { Q7 } & 0.53 & -- \\ \text { Q8 } & -- & 0.61 \\ \text { Q9 } & -- & 0.24 \\ \text { Q10 } & -- & 0.37 \\ \text { Q11 } & -- & 0.27 \\ \text { Q12 } & -- & 0.34 \\ \text { Q13 } & -- & -0.12 \\ \text { Q14 } & -- & 0.02\end{array}$

Komposit reliabilitas terkadang juga disebut sebagai konstruk reliabilitas (construct reliability). Menurut Raykov, tingkat cut-off untuk dapat memberikan keputusan bahwa reliabilitas komposit cukup bagus adalah 0.6.

Reliabilitas komposit variable hedonic dihitung sebagai berikut :

$$
\begin{gathered}
\rho=\frac{(\Sigma \lambda)^{2}}{(\Sigma \lambda)^{2}+\Sigma(\Theta)} \\
\frac{(3.1)^{2}}{(3.1)^{2}+(3.6)}=0.756
\end{gathered}
$$

Reliabilitas komposit untuk variable latent hedonic reliable dengan pencapaian koefisien 0.756 (p-values $\geq 0.6)$.

$$
\rho=\frac{(\Sigma \lambda)^{2}}{(\Sigma \lambda)^{2}+\Sigma(\Theta)}
$$

$$
=\frac{(2.83)^{2}}{(2.83)^{2}+(4.26)}=0.651
$$

Reliabilitas komposit untuk variable latent eudamonic reliable dengan pencapaian koefisien 0.631 (p-values $\geq 0.6$ ).

\section{ANALISIS DAN PEMBAHASAN}

Confirmatory Factor

Analysis adalah tehnik untuk melakukan konfirmasi mengenai konsistensi suatu teori dan konstruk. Penelitian ini dilakukan untuk mengetahui konsistensi dari WEMWBS secara cross culture. Beberapa indikator bahkan memiliki faktor loading yang kurang dalam menjelaskan kesejahteraan mental dari sisi psikis (eudemonic). Model ini menguji satu jenis model saja dengan menggunakan satu jenis syntax dalam membuat model pengukuran, (hanya mengkorelasikan antara hedonis dengan 7 indikatornya, dan eudemonic dengan 7 indikatornya). Kemungkinan pengembangan model masih terbuka dengan melakukan cross path terhadap indikator hedo dengan variabel latent eudemonic.

Diatas sudah dijelakan bahwa memodifikasi model (walaupun fit antara teori dengan model) dengan membiarkan terjadi kovalen error antar item, sebisa mungkin dihindari jika teorinya tidak kuat (robust). Beberapa item yang memiliki faktor loading yang rendah kurang bisa menjelaskan aspek kesejahteraan mental dari sisi psikis. Item yang 
kurang tepat dalam mengukur konstruk eudemonic, karena perbedaan persepsi dan budaya pada item eudemonic mengenai kesejahteraan yang berhubungan dengan kondisi psikologis. Pada Negara berkembang, konsep sejahtera secara psikologis kurang "diminati", kebanyakan konsep sejahtera dikorelasikan dengan pencapaian, dan kekayaan (materi). Selain itu dimensi budaya kita juga mengatur mengenai ekspresi tentang emosi yang akan dikeluarkan. Item item dengan wording, merasa percaya diri, merasa berenergi, merasa hebat dan dicintai adalah suatu ekspresi emosi yang kurang lazim ditemui dalam budaya kita dan cenderung ditekan (culture display rule dan feeling display rule).

Lebih dari itu peneliti melihat dengan kacamata filosofis, dengan melihat kualitas faktor loading yang hanya sebesar 0.65 (terbesar), bisa diambil kesimpulan secara statistic bahwa indikator - indikator ini lemah dalam menjelaskan aspek kesejahteraan mental, namun kalkulasi perhitungan mental tidak berhenti disitu saja, jika indikator kesejahteraan mental tidak valid dalam menjelaskan aspek kesejahteraan mental dilapangan maka dapat diambil dua kesimpulan. 1) indikator tersebut berbeda dengan indikator kesejahteraan yang dipahami oleh subjek selama ini, yang kedua adalah 2) indikator mengenai kesejahteraan mental ini memang sedang absen atau sedang tidak dialami oleh sebagian besar subjek selama 2 minggu berturut turut, dengan kata lain kondisi kesejahteraan mentalnya ketika mengisi data penelitian adalah rendah. Jika seperti itu maka indikator kesejahteraan mental tidak mengukur apa yang seharusnya diukur, seperti halnya mengukur kecemasan individu yang hidup didesa dengan memakai tolak ukur skala kecemasan individu yang tinggal di kota.

Perbandingan penggunaan software komersil dengan freeware open-source ternyata tidak melihatkan perbedaan yang sangat jauh. Koefisien dari beberapa tehnik analisis memperlihatkan open source $\mathrm{R}$ tidak berbeda jauh dengan Lisrel, dengan kata lain $\mathrm{R}$ mampu mengimbangi ketepatan dan reliabilitas dalam analisis data terhadap software komersil.

Analisis model pengukuran dan model struktural dari WEMWBS adaptasi ke bahasa Indonesia tidak seluruhnya valid merepresentatifkan dua faktor hedonic dan eudemonic. Aitem yang tidak mengukur dengan tepat faktor eudamonic, karena perbedaan persepsi dan budaya mengenai kesejahteraan mental secara psikologis. Sedangkan aitem yang tidak mengukur dengan tepat faktor hedonic, karena dimungkinkan aitem tersebut dapat membentuk konstruk baru. 


\section{DAFTAR PUSTAKA}

Anatasi, A., \& Urbina, S. 1997. Psychological Testing (7th edition). New York: Macmillan

Angner, E. 2011. Subjective well being. The Journal of SocioEconomics 39 (2010) 361-368.

Bartram, D, J. Yadegarfar, G. Sinclair, J, M, A. \& Baldwin, D, S. 2011. Validation of the Warwick-Edinburgh Mental Well-being Scale (WEMWBS) as an overall indicator of population mental health and well-being in the UK veterinary profession.The Veterinary Journal 187 (2011) 397-398.

Bornstein, M, H. Davidson, L. Keyes, C, L, M.\& Moore, K, A. 2003. Well-Being - Positive Development Accros The Life Course. Mahwah, New Jersey. Lawrence Erlbaum Associates, Inc.

Brown, T, A. 2006. Conformatory Factor Analysis for Applied Research. The Guilford Press. America, USA.

Feldt, L. S., \&Brennan, R. L. 1989.Reliability. In R. H. Linn (Ed.), Educational measurement (3rd ed.). New York: Macmillan.

Gorard, S. \& Taylor, C. 2004.Combining Methods in Educational and Social Research. USA. Open
University Press McGraw-Hill Education.

Graham, J, M. 2006.Congeneric and (Essentially) Tau-Equivalent Estimates of Score Reliability What They Are and How to Use Them. Educational and Psychological Measurement. Volume 66, Number 6, December 2006 930-944

Hair, J.F, R.E. Anderson, R.L. Thatam, \& W.C. Black. 1995. Multivariate Data Analysis With Reading, 4Thedition. Englewood Cliffs, NJ: Prentice Hall.

Harrington, D.2009. Confirmatory Factor Analysis. New York: Oxford University Press.

Hooper, D., Coughlan, J., \& Mullen, M. 2008. Structural Equation Modelling : Guidelines for Determining Model Fit Structural equation modelling : guidelines for determining model fit. Journal of Business Research, 6, 53-60.

Humphreys, D, K. Goodman, A. \& Ogilvie, D. 2013. Associations between active commuting and physical and mental wellbeing. Preventive Medicine, 57, (2013), $135-139$.

Jackson, Y. 2006. Encyclopedia of Multicultural Psychology. Thousand Oaks, California. Sage Publication, Inc.

Jöreskog, K. G., \& Sörbom, D. 2004. LISREL 8: User's Reference Guide. Chichago: Scientific Software International. 
Jorgensen, B, S. Jamieson, R, D, \& Martin, J, F. 2010. Income, sense of community and subjective well-being: Combining economic and psychological variables. Journal of Economic Psychology 31 (2010) $612-623$.

Keith, K, D. 2011. Cross-Cultural Psychology - Contemporary Themes and Perspectives. Willey - Blackwell. A John Wiley \& Sons, Ltd., Publication

Kenny, D. A., Kashy, D. A., \& Bolger, N. 1998. Data analysis in social psychology. In D. Gilbert, S. Fiske, \& G. Lindzey (Eds.), The handbook of social psychology (Vol. 1, 4th ed., pp. 233-265). Boston, MA: McGraw-Hill.

Kline, R. B. 2011. Principles and Practice of Structural Equation Modeling (3rded). In David A. Kenny (Eds.), Methodology in the Social Sciences.New York: The Guilford Press.

Mason, P. \& Kearns, A. 2013. Physical activity and mental wellbeing in deprived neighbourhoods. Mental Health and Physical Activity, 6 (2013), $111-117$.

McGrath, R, E. 2011. Quantitative Model of Psychology. USA. Washington D. C. American Psychological Association, Press.
Moore, M. Bates, M, BrierleyBwers, P. Taafe, P, \& Clymer, R. 2012. Well Being and Its Measurement. Defence Centers of Excellent for Psychological Health and Traumatic Brain Injures.

Newbigging K, Bola M, Shah A: Scoping exercise with Black and minorityethnic groups on perceptions of mental wellbeing in Scotland. Scotland: NHSHealth; 2008. http://www.healthscotland.com/ documents/2803.aspx.

Padilla, A. M., \& Borsato, G. N. 2008. Issues in Culturally Appropriate Psychoeducational Assessment. In L. A. Suzuki, \& J. G. Ponterotto (Eds.), Handbook Of Multicultural Assessment : Clinical, Psychological, and Educational Applications (3rd ed., pp. 5-21). New Jersey: John Willey \& Sons.

Proctor, R, W. \& Capaldi, E, J. 2006. Why Science Matters Understanding The Methods of Psychological Research. USA. Blackwell Publishing.

Phye, G, D. Robinson, D, H. \& Levin, J, R. 2005. Empirical Methods for Evaluating Educational Interventions. San Diego, USA. Elsevier Academic Press.

Rao, C, R. \& Sinharay, S. 2007. The Handbook of Statistics on Psychometrics - Volume 
26.USA. 2007 Elsevier B.V. All rights reserved.

Ryan, M, R. \& Huta, V. 2009. Wellness of Healthy Functioning or Wellness as Happiness :the importance of eudemonic thinking. The Journal of Postive Psychology Vol 4, No.3, pp $202-204$.

Ryan, M, R. \& Deci, E, L. 2000. The "What" and "Why" of Goal Pursuits: Human Needs and the Self-Determination of Behavior. Psychological Inquiry, 2000, Vol 11, No 4, pp 227 - 268.

Raykov, T. 2007. Reliability if deleted, not 'alpha if deleted' : Evaluation of Scale Reliability Following Component Deletion. British Journal of Mathematical and Statistical Psychology (2007), 60, 201-216.

Raykov, T. 1997. Estimation of composite reliability for congeneric measures. Applied Psychological Measurement, 21, 173-184.

Robert, P. 2006. Reliability and validity in research.Journal ofNursing Standard. 20, 44, $41-$ 45.

Rentfrow, P, J. Mellander, C. \& Florida, R. 2009. Happy States of America: A state-level analysis of psychological, economic, and social well-being. Journal of Research in Personality 43 (2009) 10731082.
Sacolo, H, N. Chung, M, H. Chu, H. Liao, Y, M. Chen, C, H. Liang Ou, K. I Chang, L. \& Chou, K, R. 2013. High Risk Sexual Behaviors for HIV among the In-SchoolYouth in Swaziland: A Structural Equation Modeling Approach. PLos ONE July 2013 | Volume 8 | Issue 7 | e67289.

Sawilowsky, S. S.2007. Construct Validity. In Neil J. Salkind (Eds.), Encyclopedia of Measurement and Statistics.(pp.178-180).

Shanafelt, T, D. Novotny, P. Johnson, M, E. Zhao, X. Steensma, D, P. Lacy, M, Q. Rubin, J. \& Sloan, J. 2005. The Well-Being and Personal Wellness Promotion Strategies of Medical Oncologists in the North Central Cancer Treatment Group. Laboratory/Clinical Translational Research Oncology, 2005 ; 68: 23-32.

Shiraev, E, B. \& Levy, D, A. 2010.Cross - Cultural Psychology - Critical Thinking and Contemporary Application. Boston, New York. Pearson Education, Inc., publishing as Allyn \& Bacon.

Sireci, S. G. 2007. Content Validity.In Neil J. Salkind (Eds.), Encyclopedia of Measurement and Statistics (pp.181-183). Thousand Oaks: Sage Publications.

Snyder, C, R. \& Lopez, S, J. 2002.Handbook of Positive 
Psychology. Oxford University Press

Socan, G. 2000. Assesment of Reliability When Test Items Are Not Essentially t-Equivalent. Developments in Survey Methodology Metodološki zvezki, 15, Ljubljana: FDV, 2000 .

Taggart, F. Friede, T. Weich, S. Clarke, A. Johnson, M. \& Stewart-Brown, S. 2013. Cross cultural evaluation of the Warwick- Edinburgh mental well-being scale (WEMWBS) a mixed methods study. Health and Quality of Life Outcomes, 2013, 11:27.

Talbott, W, J. 2010. Human Right and Human Well Being. Oxford, New York. Oxford University Press, Inc.

Tennant, R. Hiller, L. Fishwick, R, Platt, S. Joseph, S, Weich S. Parkinson, J. Secker, J. \& Stewart-Brown, S. 2007. The Warwick-Edinburgh Mental Well-being Scale (WEMWBS) : development and UK validation. Health and Quality of Life Outcomes 2007, 5:63.

Thompson, B. 2004. Exploratory and Confirmatory Factor Analysis -
Understanding Concept and Applications. Washington, D.C. American Psychological Association.

Tokuda, Y. Doba, N. Butler, J, P. \& Paasche-Orlow, M, K. 2009. Health literacy and physical and psychological wellbeing in Japanese adults. Patient Education and Counseling 75 (2009) 411-417.

Urbina, S. 2004. Essentials of Psychological Testing. New Jersey: John Willey \& Sons.

Viera, A, L. 2011. Interactive LISREL in Practice - getting started with a SIMPLIS approach. Springer Heidelberg Dordrecht London New York.

Wajsblat, L, L. 2011. Positive Androgyny and Well Being : A Positive Psychological Perspective on Gender Role. Dissertation, Hemstead, Hofstra University.

Zapalla, C, R. 2007. Well Being : The Correlation Between Self Transcendence, Psychological and Subjective Well Being. Dissertation. Institute of Transpersonal Psychology Palo Alto, California October 25, 2007. 